\title{
Tantangan dan Strategi Rekrutmen di Indonesia
}

\author{
Endro Puspo Wiroko \\ Universitas Pancasila, Jalan Raya Lenteng Agung Timur No. 56-80 Jakarta Selatan \\ e-mail:puspowiroko@gmail.com
}

\begin{abstract}
This study aims to see the current picture of recruitment in Indonesia. The research used survey method which was then analyzed thematically. Research subjects were 46 participants who worked in the field of recruitment with varied rank and seniority. The main findings related to the recruitment process are summarized based on participant responses. First, the majority of respondents argued that recruitment is currently very challenging considering on one hand the presence of less qualified candidates or even on the other hand the company does have a high enough demands. Second, given the budgetary problems, companies must adjust their recruitment strategies to their internal conditions. Finally, a recruit must have certain abilities such as target orientation, networking, negotiation, and analytic thinking. The results of this descriptive study can be used as a basis for further research and for recommendations on recruitment discussion forums. This study is limited to respondents from private companies, further research is suggested to increase the number of representative samples and develop more specific instruments.
\end{abstract}

Keywords: recruitment in Indonesia, human resources, recruitment challenge

\begin{abstract}
Abstrak
Penelitian ini bertujuan melihat gambaran terkini tentang rekrutmen di Indonesia. Penelitian menggunakan metode survey yang kemudian dianalisa secara tematik. Subjek penelitian sebanyak 46 orang partisipan yang bekerja di bidang rekrutmen dengan pangkat dan senioritas yang bervariasi. Temuan-temuan utama terkait proses rekrutmen disimpulkan berdasarkan jawaban-jawaban partisipan. Pertama, mayoritas responden berpendapat bahwa rekrutmen saat ini sangat menantang mengingat di satu sisi adanya kandidat yang kurang berkualitas atau bahkan di sisi lain perusahaan memang memiliki tuntutan cukup tinggi. Kedua, mengingat permasalahan anggaran, perusahaan harus menyesuaikan strategi rekrutmen mereka dengan kondisi internalnya. Terakhir, rekruter harus memiliki kemampuan-kemampuan tertentu seperti berorientasi pada target, menjalin jaringan, negosiasi, dan berpikir analitik. Hasil penelitian deskriptif ini dapat digunakan sebagai dasar bagi penelitian selanjutnya dan juga dapat direkomendasikan pada sejumlah forum sumber daya manusia. Penelitian ini terbatas pada responden dari perusahaan swasta, peneliti selanjutnya disarankan untuk menambah jumlah sampel yang representatif serta menyusun instrumen yang lebih spesifik.
\end{abstract}

Kata Kunci: rekrutmen di Indonesia, sumber daya manusia, tantangan rekrutmen

\section{Pendahuluan}

Persaingan dunia usaha secara global menuntut manajemen perusahaan harus lebih peduli dalam mengelola sumber daya manusia di dalamnya. Spector (2012) menyebutkan bahwa saat ini perusahaan tidak hanya sekedar membutuhkan sumber daya manusia yang hanya sekedar mengisi kebutuhan, namun juga sumber daya manusia yang memang memiliki kompetensi yang memadai dan berkomitmen tinggi. Proses pengelolaan sumber daya manusia pada umumnya meliputi rekrutmen dan seleksi, pelatihan dan pengembangan, remunerasi, terminasi, dan juga berbagai perilaku karyawan yang dapat memberikan dampak pada berjalannya proses kerja (Landy dan Conte, 2013).

Pengelolaan karyawan yang baik berawal dari pengelolaan proses rekrutmen yang baik pula (Mello, 2015). Rekrutmen merupakan garda depan dari proses pengelolaan sumber daya manusia. Keputusan untuk merekrut karyawan baru merupakan keputusan penting bagi 
perusahaan manapun (Billsberry, 2007). Pihak perusahaan harus mampu merekrut kandidat yang tidak hanya cocok untuk pekerjaan yang dimaksud namun juga karyawan tersebut harus cocok dengan budaya perusahaan. Saat ini merekrut kandidat terbaik yang sesuai dengan kebutuhan perusahaan sudah menjadi tantangan tersendiri. Pihak perusahaan harus mampu menarik perhatian sejumlah orang yang potensial untuk mengisi posisiposisi kosong yang perlu segera diisi oleh karyawan yang tepat (Chapman, Uggerslev, Carroll, Piasentin, dan Jones, 2005).

Guna memudahkan proses perekrutan calon tenaga kerja, maka pihak perusahaan harus mempunyai kumpulan data kandidat yang banyak (Spector, 2012). Ketika pihak perusahaan memiliki simpanan data yang berisi banyak pilihan calon kandidat, maka dengan mudah rekruter akan memilih calon kandidat dari kumpulan data tersebut.

Secara ideal, suatu proses rekrutmen ditujukan untuk menghimpun kumpulan data tentang kandidat-kandidat yang dinilai prospektif untuk diseleksi lebih lanjut (Alonso, 2014), sehingga pihak perusahaan yang diwakili oleh rekruter dapat dengan mudah memilih calon kandidat kapan saja sesuai kebutuhan. Berbagai alat dan metode yang digunakan dalam rekrutmen harus disesuaikan dengan karakteristik calon kandidat yang menjadi target sehingga mereka tertarik untuk membaca iklan lowongan kerja yang sudah dibuat. Selanjutnya tentunya diharapkan agar para calon kandidat berkeinginan melamar posisi yang sedang dibutuhkan.

Sejumlah penjelasan di atas merupakan kondisi ideal dari suatu proses rekrutmen. Akan tetapi, berdasarkan pengalaman langsung peneliti, rekrutmen saat ini sudah semakin menantang. Beberapa tahun ke belakang, peneliti pernah bekerja di bidang sumber daya manusia dan menemukan fakta bahwa menjalankan proses rekrutmen itu tidak semudah seperti yang terlihat. Kesulitan yang dimaksud yaitu sulitnya menentukan metode yang tepat dalam menjaring calon kandidat yang sesuai dengan kriteria yang diharapkan (Berger dan Berger, 2011)

Pendapat peneliti ini didukung oleh Cosseboom (2014) yang menulis bahwa menurut The Boston Consulting Group, menjelang tahun 2020 perusahaanperusahaan besar di Indonesia hanya akan mampu mengisi sekitar separuh dari keseluruhan jumlah posisi-posisi pemula dengan orang-orang yang sepenuhnya berbakat. Selain itu, Dessler dan Huat (2009) menyebutkan bahwa walaupun Indonesia memiliki kelebihan jumlah tenaga kerja namun bidang-bidang tertentu akan sangat sulit dalam menemukan kandidat yang berbakat.

Topik penelitian tentang rekrutmen mulai marak dibicarakan akhir-akhir ini (Billsberry, 2007) namun peneliti merasa perkembangannya di Indonesia belum terlihat. Sejauh pengetahuan peneliti, bidang Psikologi Industri dan Organisasi di Indonesia pun sangat jarang menyentuh area rekrutmen dan seleksi. Berdasarkan sejumlah fakta di atas, peneliti tertarik untuk mendalami secara lebih komprehensif tentang gambaran rekrutmen terkini di Indonesia. Sejauh pengetahuan peneliti, hingga penelitian ini dilakukan belum ada informasi tentang gambaran rekrutmen di Indonesia. Oleh karena itu, signifikansi dari penelitian deskriptif ini adalah mengisi kekosongan informasi tersebut guna menjadi landasan bagi penelitian selanjutnya.

Rekrutmen adalah proses menjaring calon-calon karyawan baru yang potensial agar mereka melamar pekerjaan sesuai dengan lowongan yang ada, sedangkan seleksi adalah menentukan pilihan kandidat mana yang akhirnya dipilih berdasarkan kriteria yang ada (Snell dan Bohlander, 2010). Rekrutmen dan seleksi dapat dilakukan setelah manager terkait memanfaatkan analisa jabatan untuk menentukan karakter dan kriteria individu yang ingin mereka pekerjakan (Landy dan Conte, 2013). 
Rekrutmen dan seleksi berjalan secara beriringan karena sebenarnya kedua hal tersebut adalah proses yang berjalan dalam suatu siklus. Hanya saja, peneliti memutuskan untuk fokus pada rekrutmen walaupun dimungkinkan nantinya akan didapatkan fakta seputar seleksi dalam temuan data.

Terkait metode yang biasa digunakan dalam proses menarik perhatian para calon kandidat, Schultz dan Schultz (2006) menyebutkan bahwa sejumlah metode yang lazim dilakukan diantaranya memasang iklan lowongan kerja pada job portal, media massa, bursa kerja, rekrutmen kampus, dan bisa juga dilakukan dengan melakukan referral program. Semua metode tersebut tergolong dalam rekrutmen eksternal. Sedangkan metode yang termasuk ke dalam rekrutmen internal pada dasarnya adalah pemindahan karyawan baik secara promosi, mutasi, maupun transfer. Setiap perusahaan memiliki teknik rekrutmen yang berbeda-beda tergantung pada kebutuhan dan kondisi masing-masing perusahaan tersebut.

Penelitian ini sebenarnya berangkat dari belum adanya literatur yang mampu menjelaskan tentang masalah-masalah terkait rekrutmen di Indonesia. Oleh karena itu, tujuan dari penelitian ini memang masih umum yaitu menemukan masalah apa saja yang sering muncul dalam proses rekrutmen di Indonesia. Ketertarikan peneliti telah mendorong untuk dilakukannya penelitian awal ini untuk menangkap gambaran mengenai tren-tren umum yang sedang terjadi di bidang rekrutmen melalui perspektif rekruter perusahaan maupun rekruter yang bekerja sebagai pihak ketiga.

Gambaran umum yang dimaksud adalah bahwa peneliti ingin mengetahui aspek-aspek yang menjadi tantangan dalam rekrutmen sekaligus juga strategi apa saja yang sekiranya dapat digunakan untuk menjawab tantangan tersebut. Selain itu, kualitas dari para rekruter pun menarik untuk ditanyakan. Hasil dari penelitian ini akan disampaikan kepada pihak-pihak yang bekerja di bidang sumber daya manusia. Berdasarkan hasil akhir, peneliti bermaksud melanjutkan penelitian ini jika nantinya ditemukan fenomena yang menarik dan memiliki urgensi untuk diteliti lebih lanjut.

\section{Metode Penelitian}

Penelitian ini menggunakan metode deskriptif. Responden adalah orang yang bekerja di bidang rekrutmen baik sebagai internal rekruter untuk perusahaan maupun rekruter yang bekerja sebagai pihak ketiga.

Instrumen dalam penelitian ini berupa tiga pertanyaan terbuka tentang bagaimana pendapat mereka terkait (i) kondisi rekrutmen terkini di Indonesia, (ii) strategi dalam menghadapi kondisi tersebut, dan (iii) keahlian yang wajib dimiliki oleh para rekruter. Pertanyaan-pertanyaan tersebut tidak diturunkan dari teori manapun karena tujuan peneliti adalah mengumpulkan informasi awal.

Kuesioner online dipilih karena alasan praktis. Kontrol terhadap responden dilakukan dengan memeriksa profil responden melalui LinkedIn atau dengan menghubungi mereka melalui telepon secara acak.

Setelah mengumpulkan semua jawaban, peneliti mengkategorikan jawabanjawaban tersebut berdasarkan kemiripan makna. Analisa tematik sederhana membantu peneliti untuk mengelompokkan jawaban-jawaban serupa untuk kemudian diklasifikasikan ke dalam kelompokkelompok yang lebih spesifik. Walaupun beberapa responden ada yang memberikan jawaban-jawaban seputar seleksi, namun yang diolah hanya jawaban seputar rekrutmen. Ketika menemukan jawaban yang kurang jelas, maka peneliti bertanya kepada responden melalui telepon.

\section{Hasil Penelitian dan Pembahasan}

Sebanyak 46 responden mengisi kuesioner yang mereka terima. Mereka memiliki tingkatan jabatan dan masa kerja yang berbeda-beda. Kemudahan dalam akses membuat peneliti hanya mendapatkan 
data dari responden (baik rekruter internal perusahaan maupun rekruter pihak ketiga) yang bekerja di perusahaan swasta. Oleh karena itu, tren dari rekrutmen selain perusahaan swasta tidak ada dalam analisa.

Tabel 1

Karakteristik Responden

\begin{tabular}{llc}
\hline Kriteria & Responden & Persentase \\
\hline Jenis kelamin & Laki-laki & $35 \%$ \\
& Perempuan & $65 \%$ \\
Tingkat jabatan & Staf & $42 \%$ \\
& Supervisor & $43 \%$ \\
& Manager & $15 \%$ \\
Masa kerja & $1-2$ tahun & $54 \%$ \\
& $2-4$ tahun & $36 \%$ \\
& 4 tahun ke atas & $10 \%$ \\
\hline
\end{tabular}

Penelitian ini menggunakan konteks rekrutmen dalam perspektif baik rekrutmen internal perusahaan maupun rekrutmen pihak ketiga. Di bawah ini adalah jawabanjawaban dari para responden.

Tabel 2

Jawaban Responden

\begin{tabular}{|c|c|c|}
\hline $\begin{array}{l}\text { Perta- } \\
\text { nyaan }\end{array}$ & Jawaban & Persentase \\
\hline \multirow[t]{7}{*}{$\mathrm{i}$} & $\begin{array}{l}\text { Kurangnya kandidat yang } \\
\text { memenuhi kualifikasi }\end{array}$ & $24 \%$ \\
\hline & $\begin{array}{l}\text { Keberadaan headhunter } \\
\text { memberikan efek ganda }\end{array}$ & $21 \%$ \\
\hline & $\begin{array}{l}\text { Permasalahan biaya } \\
\text { (anggaran) }\end{array}$ & $19 \%$ \\
\hline & $\begin{array}{l}\text { Munculnya alat-alat } \\
\text { rekrutmen baru }\end{array}$ & $14 \%$ \\
\hline & $\begin{array}{l}\text { Persaingan dengan } \\
\text { perusahaan start-up }\end{array}$ & $10 \%$ \\
\hline & $\begin{array}{l}\text { Adanya kelompok } \\
\text { millennial yang sangat } \\
\text { selektif }\end{array}$ & $8 \%$ \\
\hline & Lainnya & $4 \%$ \\
\hline \multirow[t]{5}{*}{ ii } & $\begin{array}{l}\text { Menyelaraskan kembali } \\
\text { strategi rekrutmen } \\
\text { perusahaan }\end{array}$ & $29 \%$ \\
\hline & $\begin{array}{l}\text { Mempelajari kembali } \\
\text { tentang posisi yang dicari } \\
\text { dan proses bisnis }\end{array}$ & $26 \%$ \\
\hline & Adanya program referral & $23 \%$ \\
\hline & $\begin{array}{l}\text { Adanya program company } \\
\text { branding }\end{array}$ & $15 \%$ \\
\hline & Lainnya & $7 \%$ \\
\hline \multirow[t]{2}{*}{ iii } & Orientasi kepada target & $27 \%$ \\
\hline & $\begin{array}{l}\text { Kemampuan menjalin } \\
\text { jaringan }\end{array}$ & $23 \%$ \\
\hline
\end{tabular}

\begin{tabular}{lc}
\hline $\begin{array}{l}\text { Kemampuan komunikasi } \\
\text { dan negosiasi }\end{array}$ & $23 \%$ \\
$\begin{array}{l}\text { Kemampuan berpikir } \\
\text { analitik }\end{array}$ & $19 \%$ \\
Lainnya & $8 \%$ \\
\hline
\end{tabular}

Bagian selanjutnya merupakan penjelasan dari jawaban-jawaban yang muncul. Peneliti berusaha untuk memperkaya temuan yang ada dengan mengaitkannya berdasarkan literatur yang sudah ada.

Mengawali pemaparan hasil, peneliti memulai dengan pertanyaan pertama yaitu tren-tren terkait kondisi rekrutmen terkini di Indonesia. Sejumlah besar (24\%) responden menjelaskan tentang kelangkaan dalam mendapatkan kandidat yang benarbenar memenuhi kualifikasi. Kondisi ini mereka anggap sebagai aspek yang paling berpengaruh terkait kondisi rekrutmen. Menurut responden, saat ini sangat sulit untuk mendapatkan kandidat yang keahlian dan kompetensinya sepenuhnya sesuai dengan spesifikasi pekerjaan. Menurut jawaban responden, ada banyak sekali lamaran yang masuk, namun kandidat yang tepat jumlahnya sangat terbatas.

Karyawan baru yang akhirnya dipekerjakan oleh pihak perusahaan sebaiknya adalah individu yang memenuhi kualitas person-job fit dan juga personorganization fit (Landy dan Conte, 2013). Person-job fit menjelaskan tentang sejauhmana keahlian, kemampuan, dan minat seseorang sejalan dengan kebutuhan suatu pekerjaan. Person-organization fit menjelaskan tentang sejauhmana nilai-nilai seorang karyawan konsisten dengan nilainilai yang dipegang oleh sebagian besar orang lain di perusahaan.

Sejumlah responden menjelaskan bahwa tidak jarang mereka berhadapan dengan kondisi dimana akhirnya tingkat fit tidaknya kandidat menjadi tidak terlalu diutamakan. Hal ini disebabkan mencari kandidat yang sangat fit memang sangat tidak mudah. Ketika seorang kandidat yang dirasa cocok sudah ditemukan, maka tren yang seringkali terjadi saat ini adalah kandidat tersebut akan menyebutkan 
ekspektasi gaji yang tinggi dan menyampaikan sejumlah hal transaksional bahkan ketika proses rekrutmen dan seleksi belum selesai. Namun tetap saja pada dasarnya para responden mengaku bahwa mereka akan mengusahakan sebaik mungkin untuk mendapatkan kandidat yang paling sesuai.

Tidak dapat dipungkiri bahwa biasanya kandidat yang berhasil memenuhi kualifikasi adalah kandidat yang banyak dicari oleh perusahaan-perusahaan lain. Dalam kondisi sulit mencari kandidat terbaik, beberapa user dari suatu jabatan ada yang bersedia menurunkan ekspektasi, namun tidak sedikit juga yang bertahan pada ekspektasi yang tinggi. Padahal situasi yang terjadi adalah bahwa suatu posisi yang kosong harus sesegera mungkin diisi, namun di sisi lain ada perusahaan lain yang juga sedang mengincar orang berbakat untuk mengisi posisi sejenis. Belum lagi, perusahaan tempat kandidat berbakat tersebut bekerja pasti berusaha keras dalam mempertahankan orang tersebut agar tetap bertahan dan tidak pindah ke perusahaan lain.

Orang-orang yang bekerja di bidang sumber daya manusia menyebut situasi ini sebagai "war of talent". Orang-orang yang berbakat adalah mereka yang jumlahnya sangat terbatas, mampu memberikan kontribusi maksimal kepada organisasi, dan orang-orang ini perlu dihargai, diperhatikan, dan dikembangkan potensinya agar mampu memberikan dampak positif sebesar-besarnya bagi organisasi atau perusahaan (Chowdury, 2002). Perusahaanperusahaan bersaing untuk menarik orangorang berbakat sedangkan para kandidat terbaik tersebut banyak sekali yang "jual mahal".

Aspek penting kedua yang dibahas terkait pertanyaan pertama mengenai tren rekrutmen adalah kemunculan headhunter yang semakin marak. Sejumlah responden (21\%) menyebutkan bahwa akhir-akhir ini semakin banyak bermunculan headhunter baik lokal maupun multinasional, dan bahkan ada juga yang dikelola secara individual.

Responden menilai adanya efek ganda yang ditimbulkan oleh headhunter ini. Sejumlah rekruter internal perusahaan merasa terbantu dengan keberadaan headhunter karena headhunter dinilai memiliki kumpulan data calon kandidat yang lebih besar dan lebih lengkap dibandingkan dengan rekruter internal perusahaan. Untuk beberapa kondisi dan kebutuhan tertentu, mendapat bantuan dari headhunter akan menguntungkan. Hal ini sejalan dengan Landy dan Conte (2013) yang menyebutkan bahwa bekerjasama dengan headhunter memang menjadi salah satu alat rekrutmen yang efektif untuk posisi tertentu.

Di sisi lain, sejumlah rekruter internal perusahaan lainnya berargumen bahwa terkadang jasa headhunter dapat disimpan terlebih dahulu. Mereka dinilai tidak selalu mampu memberikan pilihan kandidat dengan kualifikasi yang baik padahal mereka sudah menetapkan biaya mahal.

Jawaban-jawaban tersebut datang dari para rekruter internal perusahaan yang melihat dua sisi keberadaan headhunter. Sedangkan jika kita perhatikan, respon dari headhunter memang cenderung lebih banyak mengungkapkan sisi positif keberadaan mereka. Headhunter merasa bahwa rekruter internal perusahaan tidak mampu melakukan hal tertentu misalnya menarik perhatian calon kandidat yang masih bekerja di perusahaan pesaing. Headhunter juga merasa bahwa mereka mampu menurunkan beban kerja para rekruter internal perusahaan.

Masalah biaya (anggaran) yang dinilai oleh para responden (19\%) menjadi aspek penting ketiga terkait kondisi rekrutmen. Berdasarkan penjelasan responden, sebagian besar perusahaan di Indonesia saat ini (saat penelitian ini dilakukan) sedang memfokuskan diri dalam memperketat pengeluaran. Padahal sebenarnya anggaran yang disusun secara tepat di awal tahun anggaran akan mendukung keberlangsung- 
an proses rekrutmen dengan baik (Alonso, 2014).

Penghematan ini terjadi pada hampir semua divisi di perusahaan termasuk rekrutmen. Beberapa industri sedang tidak menunjukkan kinerja yang memuaskan dan bahkan beberapa industri lain sedang melakukan "pembekuan" terhadap proses rekrutmen mereka. Rekruter internal perusahaan harus bekerja lebih keras dalam mencari dan menarik perhatian kandidat terbaik dengan kondisi anggaran yang sangat terbatas. Dalam kondisi anggaran yang terbatas, maka para rekruter internal perusahaan harus menunda permintaan bantuan kepada headhunter karena biaya yang ditawarkan oleh headhunter seringkali tidak sesuai dengan anggaran yang ada.

Aspek keempat yang disebutkan oleh responden (14\%) adalah bahwa alat-alat rekrutmen akhir-akhir ini lebih variatif. Alat rekrutmen yang dimaksud adalah semakin banyaknya job portal baru dan juga pemanfaatan media sosial untuk menyebarkan iklan lowongan kerja. Kapse, Patil dan Patil (2012) menyarankan bahwa menarik perhatian kandidat saat ini dapat dilakukan dengan menciptakan alat rekrutmen elektronik (e-recruitment) tersendiri yang disusun sesuai kebutuhan perusahaan. Tautan untuk rekrutmen elektronik biasanya dapat dilihat langsung di situs perusahaan. Desain dan konten dari halaman rekrutmen pada situs perusahaan harus dibuat atraktif agar menarik calon kandidat untuk melamar (Allen, Biggane, Pitts, Otondo dan Scotter, 2013).

Kapse dkk. (2012) menjelaskan bahwa penggunaan rekrutmen online akan mempermudah rekruter dalam mengelola data pelamar. Kumpulan data yang sudah diklasifikasikan dengan baik akan mempercepat rekruter dalam mencari kandidat yang profilnya sudah masuk ke dalam database. Pengolahan dan pengelolaan database diketahui mampu mempercepat proses rekrutmen dan meningkatkan kualitas proses seleksi kandidat (Chien dan Chen, 2008). Database sebaiknya diolah dengan baik dengan cara mengelompokkan para kandidat sesuai tingkat kemungkinan mereka diterima ke dalam kelompokkelompok tertentu. Pilihan kelompok ini akan bermanfaat ketika seorang kandidat menolak tawaran, maka rekruter dapat melanjutkan pencarian kandidat dari kelompok selanjutnya (Scullen, 2013).

Mondy (2010) mengingatkan bahwa alat rekrutmen online sudah pasti tidak akan murah sehingga konten dan tampilan harus dibuat semenarik mungkin agar mampu "membujuk" orang-orang untuk melamar. Kebanyakan orang hanya membaca iklan lowongan kerja namun mereka tidak tertarik untuk melamar karena iklan yang dibaca kurang mampu menggambarkan kondisi perusahaan.

Ada beberapa responden yang menyebutkan kelemahan rekrutmen online misalnya saja bahwa rekrutmen online belum tentu cocok untuk berbagai posisi pekerjaan. Hal ini sejalan dengan Shapiro, Hoque, Kessler, Pepper, Richardson dan Walker (2013) yang juga menambahkan bahwa kemudahan akses rekutmen online justru terkadang akan membuat kandidat yang tidak sesuai kriteria akan tetap melamar. Namun para responden melihat hal ini justru sebagai keuntungan yaitu untuk memperbesar database asalkan isi kumpulan data diolah dengan baik oleh rekruter.

Masih menyangkut poin tentang maraknya alat-alat baru dalam rekrutmen, alat-alat tersebut tumbuh seiring dengan perkembangan media sosial dalam rangka peluncuran program employer branding yang semakin banyak dilakukan oleh perusahaan. Employer branding merupakan cara-cara yang dimaksudkan untuk menarik perhatian kandidat agar tertarik melamar ke perusahaan di tengah ramainya iklan-iklan lowongan kerja lain yang juga disebar oleh banyak perusahaan lain (Schultz dan Schultz, 2006).

Iklan lowongan kerja boleh saja disebarkan melalui berbagai jenis media sosial. Catatan terkait upaya ini adalah bahwa semua usaha tersebut harus 
dilakukan dengan seksama dan perlu kehati-hatian agar tidak melebihi anggaran yang ada. Rekruter juga perlu memperhatikan kode etik perusahaan guna memastikan kembali aturan apa saja yang perlu diketahui ketika ingin membuat pengumuman-pengumuman dengan menggunakan berbagai atribut perusahaan.

Oleh karena perkembangan yang pesat media sosial, responden juga mengingatkan agar para rekruter senantiasa memperbarui pengetahuan mereka tentang social networking websites sebagai sarana pemasangan iklan rekrutmen. Sejalan dengan jawaban mayoritas responden, Nikolaou (2014) menemukan bahwa jejaring sosial seperti LinkedIn dan Facebook keduanya efektif untuk menjaring kandidat. Namun memang para profesional di bidang sumber daya manusia merasa lebih efektif dengan menggunakan LinkedIn karena LinkedIn disebut sebagai jejaring sosial yang lebih sesuai untuk menarik perhatian kandidat pasif. Kandidat pasif adalah orang-orang yang tidak melamar suatu pekerjaan karena membaca iklan, namun mereka ditawarkan untuk melamar setelah rekruter membaca profil calon kandidat dan profil tersebut dirasa cocok. Hanya saja, Stoughton, Thompson, dan Meade (2015) mengingatkan bahwa rekruter perlu menunjukkan sikap positif ketika menawarkan lowongan kepada kandidat pasif karena tidak semua kandidat pasif merasa nyaman menerima informasi lowongan kerja.

Aspek kelima yang dibahas selanjutnya berhubungan dengan kemunculan sejumlah perusahaan start-up. Sejumlah 10\% responden menyebutkan bahwa persaingan tidak hanya terjadi di kalangan perusahaanperusahaan yang sudah besar dan mapan. Perusahaan kecil yang baru saja didirikan atau yang biasa disebut dengan perusahaan start-up pun sedang tumbuh berkembang pesat. Oleh karena itu, perusahaan start-up juga sedang giat mencari orang-orang terbaik untuk dipekerjakan.
Berdasarkan informasi dari para responden, sebagian besar perusahaan start-up mungkin saja kurang memberikan imbalan yang kompetitif jika dibandingkan dengan perusahaan mapan. Akan tetapi mereka mampu menawarkan sistem kerja yang dirancang khusus guna memenuhi harapan-harapan dari para kandidat terbaik mereka. Harapan tersebut diantaranya lingkungan kerja yang menyenangkan, tidak ada birokrasi, dan waktu kerja yang fleksibel.

Dinilai oleh responden (8\%) sebagai aspek yang signifikan selanjutnya, keberadaan para millennial juga dijadikan bahan pertimbangan ketika perusahaan sedang merekrut karyawan. Millennial atau yang biasa disebut dengan generasi $\mathrm{Y}$ biasa dinilai dengan label-label seperti kurangnya resiliensi namun mereka menuntut imbalan yang tinggi. Fenomena ini memang perlu ditelaah lebih lanjut, tetapi isu yang umum bagi para millennial adalah bahwa mereka sering berpindah tempat kerja dalam waktu yang singkat. Dalam kasus ini, para rekruter harus mampu memilih dan memilah sekiranya kandidat mana saja yang tidak akan terlalu menjadi "kutu loncat".

Selain aspek-aspek yang sudah disebutkan di atas, ada beberapa aspek lain yang juga masih dirasa penting oleh para rekruter. Beberapa aspek ini memiliki persentase terkecil (4\%) namun tetap menarik untuk disampaikan. Responden menyebutkan tentang kegunaan rekrutmen internal. Biasanya rekrutmen internal saat ini menjadi pilihan cukup baik ketika rekrutmen eksternal kurang menunjukkan hasil yang sesuai harapan. Rekrutmen internal dapat dijadikan salah satu cara untuk mempertahankan karyawan tertentu dimana mereka direkrut secara internal untuk menduduki posisi lebih tinggi di perusahaan yang sama. Rekrutmen internal diketahui mampu menekan biaya pengelolaan sumber daya manusia terutama rekrutmen dan pengembangan karyawan (Townsend, 2007). 
Isu tentang nepotisme untuk saat ini memang bukan menjadi masalah besar, namun isu ini ternyata masih tetap saja sesekali kita temui. Terkadang rekruter merasa sulit menolak praktik nepotisme namun tidak sedikit juga rekruter yang masih bersedia menuruti kemauan hiring manager. Meski demikian, Padgett, Padgett dan Morris (2015) menyarankan agar rekruter sedapat mungkin menghindari praktik nepotisme karena kandidat yang diperoleh melalui jalur ini tidak dapat dipastikan kualitas kerjanya di kemudian hari.

Melakukan edukasi kepada para hiring manager juga menjadi hal penting karena masih banyak di antara mereka yang bahkan belum memahami pentingnya menyusun deskripsi pekerjaan yang baik. Ketika berpedoman pada deskripsi pekerjaan yang jelas, maka rekruter akan mampu menargetkan di mana saja kemungkinan akan dapat merekrut kandidat yang sekiranya sesuai. Semua penjelasan di atas menunjukkan tentang gambaran terkini terkait kondisi rekrutmen di Indonesia.

Pembahasan selanjutnya terkait dengan pertanyaan kedua tentang strategi yang diperlukan dalam menghadapi kondisi rekrutmen di Indonesia, khususnya di perusahaan-perusahaan swasta. Pertama, rekruter $(29 \%)$ menyarankan agar perusahaan harus mampu menyelaraskan kembali strategi rekrutmen yang dijalankan dengan kondisi internal perusahaan terutama masalah anggaran. Dibantu pihak sumber daya manusia, jajaran manajemen eksekutif harus mampu menerjemahkan aspirasi mereka sehingga dapat disusun suatu rencana rekrutmen yang sejalan dengan kebutuhan perusahaan (Snell dan Bohlander, 2010).

Contohnya saja adalah penyesuaian dalam menyusun iklan yang baik. Sebaiknya harus ada strategi yang jelas dalam menentukan pemilihan job portal yang sesuai dengan kebutuhan perusahaan. Selain itu, konten dari materi iklan pun dapat diisi dengan sejumlah informasi penting yang dapat menarik perhatian para pelamar.

Kedua, pihak rekruter $(26 \%)$ merasa bahwa mereka memang harus meluangkan waktu lebih banyak untuk mempelajari kembali proses bisnis perusahaan secara umum maupun proses kerja di unit tertentu agar mereka mendapatkan gambaran lebih baik tentang karakteristik kandidat yang seharusnya direkrut. Raub dan Streit (2006) menganjurkan agar para rekruter memiliki pengetahuan yang menyeluruh tentang perusahaan dan juga posisi yang dibutuhkan.

Mayoritas responden menyarankan bahwa pengetahuan tentang perusahaan maupun rincian karakteristik pekerjaan dapat dipelajari dari berbagai dokumen maupun dengan bertanya kepada pimpinan di berbagai unit kerja. Hal ini penting agar nantinya pada saat berkomunikasi dengan kandidat, para rekruter mampu bertindak realistis, maksudnya adalah mampu menyampaikan sisi menarik dari pekerjaan bahkan juga hal-hal kurang menyenangkan yang mungkin terjadi jika kandidat akhirnya lolos pada tahap seleksi nantinya. Ditambahkan juga bahwa perilaku realistis dari seorang rekruter akan sangat membantu ketika harus merekrut orangorang untuk berbagai posisi yang memang langka sumber kandidatnya.

Saran ketiga yang diajukan rekruter $(23 \%)$ terkait strategi rekrutmen adalah dilakukannya referral program. Program ini adalah sebagai upaya dimana seorang karyawan dapat merekomendasikan orang yang ia kenal untuk dikirim datanya kepada rekruter (Breaugh, 2008). Jika program ini disusun secara matang, maka biaya rekrutmen dapat dipangkas. Tentu saja rekruter harus mampu menyusun sejumlah persyaratan dan deskripsi program yang jelas agar program ini mudah dimengerti dan didukung oleh para karyawan. Breaugh (2008) memang menyebutkan bahwa saat ini keberadaan referral program cukup dipertimbangkan setelah sejumlah metode 
rekrutmen lain seperti iklan dan agensi rekrutmen pihak ketiga.

Saran keempat yang selanjutnya diajukan rekruter $(15 \%)$ adalah bahwa branding perusahaan sangat penting untuk menarik perhatian semakin banyak kandidat. Hal ini dapat diselaraskan dengan penjelasan sebelumnya tentang maraknya pemanfaatan media sosial dalam melakukan employer branding. Ketika melakukan employer branding, rekruter akan menampilkan sejumlah keuntungan untuk bekerja di perusahaan tersebut dan berusaha menonjolkan keuntungan tersebut yang bisa saja tidak dimiliki oleh perusahaan lain. Citra (image) positif yang dilihat oleh calon kandidat akan membuatnya tertarik untuk melamar (Shapiro dkk., 2013).

Sebagai tambahan, seorang rekruter juga dinilai perlu untuk melakukan studi banding dengan rekruter lain. Program ini dapat dijalankan baik di bidang industri yang sama maupun berbeda sehingga rekruter dapat mengajukan sejumlah saran kepada manajemen guna mendukung efektivitas dan efisiensi proses rekrutmen.

Akhirnya, sebagai penutup, para rekruter mengingatkan bahwa pekerjaan rekrutmen adalah tugas yang tidak pernah akan ada habisnya. Oleh karena itu, menurut sejumlah responden, terkadang seorang rekruter tidak perlu memiliki program rekrutmen yang spesifik. Adapun yang harus dijalankan hanyalah terusmenerus menjalankan proses sourcing serta terus mampu menjaga semangat dalam bekerja.

Pertanyaan ketiga dalam penelitian ini berhubungan dengan kemampuan apa saja yang perlu dimiliki oleh rekruter. Breaugh (2008) menegaskan bahwa karakter dan perilaku rekruter akan berdampak pada respon pelamar.

Berdasarkan hasil jawaban para responden, ada beberapa kemampuan yang wajib dimiliki oleh para rekruter. Pertama, sebanyak $27 \%$ responden menjawab bahwa waktu yang cepat berjalan membuat rekruter harus mampu fokus mengejar target. Kemampuan untuk bekerja di lingkungan secara cepat, dinamis, dan tidak pasti menjadi kemampuan penting agar seorang rekruter mampu bertahan dalam pekerjaannya.

Kedua, sebanyak $23 \%$ responden menjelaskan bahwa mengandalkan iklan lowongan kerja saja tidak cukup sehingga rekruter yang baik harus mampu menampilkan kemampuan networking yang baik. Mereka harus mampu berinisiatif untuk memperluas jaringan profesional. Jaringan inilah yang akan membantu memperbanyak kumpulan data para pekerja profesional yang cepat ataupun lambat pasti akan bermanfaat ketika harus mencari kandidat.

Ketiga, sebanyak $23 \%$ responden menyebutkan bahwa rekruter harus mampu berkomunikasi dengan baik pula. Kemampuan komunikasi yang persuasif penting untuk mengajak seseorang yang dirasa memenuhi kualifikasi untuk melamar pekerjaan. Peneliti menemukan pendapat yang menjelaskan tentang pentingnya kemampuan komunikasi sebagai jembatan penghubung antara rekruter dan kandidat. Zhao dan Liden (2011) menjelaskan bahwa selama proses awal berkomunikasi dengan kandidat, seorang rekruter harus mampu menyampaikan kesan positif tentang perusahaan sehingga kandidat terus memiliki minat untuk melamar sampai selesainya proses seleksi. Kesan positif yang diterima pelamar akan memengaruhi keputusan akhir kandidat apakah ia akan mengambil suatu pekerjaan atau tidak (Klotz, Veiga, Buckley dan Gavin, 2013). Kraichy dan Chapman (2014) juga menambahkan bahwa selain kemampuan lisan diperlukan juga kemampuan menulis pesan yang baik selama proses rekrutmen. Gaya bahasa persuasif namun tetap disesuaikan dengan karakter calon kandidat akan menarik perhatiannya. Carless (2005) juga menambahkan bahwa rekruter harus mampu berkomunikasi dengan baik agar kandidat mendapatkan informasi yang lengkap baik tentang pekerjaan maupun 
perusahaan yang dituju. Dengan diberikan informasi yang cukup tersebut, diharapkan kandidat mampu mengevaluasi dirinya guna mempertimbangkan apakah ia memang cocok untuk melamar pada posisi yang ada.

Keempat, sebanyak $19 \%$ responden memaparkan bahwa kemampuan analisa juga tidak kalah penting karena rekruter harus mampu melakukan analisa secara berkala terhadap kemajuan hasil kerjanya. Analisa ini berguna untuk mengidentifikasi proses apa yang belum berjalan baik untuk segera dilakukan perbaikan (Snell dan Bohlander, 2010). Kelebihan dan kekurangan suatu alur rekrutmen perlu dianalisa agar proses rekrutmen itu sendiri mampu adaptif terhadap situasi yang mudah berubah.

Terakhir, para responden $(8 \%)$ menyebutkan bahwa kesabaran menjadi bekal penting jika seseorang ingin menjadi rekruter. Billsberry (2007) menyebutkan pentingnya kemampuan meregulasi emosi pada rekruter guna menghadapi masa-masa dimana beban kerja tinggi dan juga tuntutan tinggi dari para hiring manager.

\section{Simpulan dan Saran}

Sebagai penutup, ada beberapa temuan penting dari penelitian ini. Pertama, sebagian besar perusahaan sangat kesulitan untuk menarik kandidat yang memenuhi kualifikasi. Kedua, terkait masalah anggaran maka perusahaan harus mampu menyelaraskan kembali strategi rekrutmen dengan kondisi internal perusahaan. Ketiga, semua rekruter harus berorientasi pada target untuk mencapai hasil terbaik dalam menarik kandidat terbaik pula.

Melihat hasil akhir ini, peneliti menyarankan sejumlah poin untuk diteliti lebih lanjut diantaranya faktor-faktor apa saja yang memengaruhi seseorang untuk melamar suatu iklan lowongan pekerjaan dan juga faktor-faktor psikologis apa saja yang perlu dimiliki oleh seorang rekruter yang solid. Dari sisi kandidat, akan menarik juga untuk melihat faktor-faktor apa saja yang membuat seorang kandidat bersedia melamar pada suatu lowongan pekerjaan dan pada akhirnya menerima tawaran di perusahaan tersebut.

Terdapat beberapa keterbatasan dalam penelitian ini yang dapat dijadikan saran metodologis bagi peneliti selanjutnya. Pertama, analisa data dan kontrol terhadap responden perlu diperhatikan kembali. Supaya mampu memberikan gambaran yang lebih baik pada topik yang sama, peneliti merasa perlu untuk mengajak seorang ahli yang mampu meminimalisasi subjektivitas dalam menganalisa jawabanjawaban yang terkumpul. Kedua, penting juga untuk memfokuskan perhatian pada responden. Hal ini dapat dilakukan dengan menambah jumlah responden. Selain itu, kategorisasi yang lebih baik dapat juga dilakukan berdasarkan (1) jenis perusahaan, (2) pemisahan antara rekruter internal perusahaan dan rekruter pihak ketiga, (3) jabatan dan masa kerja responden. Ketiga, topik yang lebih spesifik di masa yang akan datang juga akan mampu memperjelas penelitian.

\section{Daftar Pustaka}

Allen, D.G., Biggane, J.E., Pitts, M., Otondo, R., \& Scotter, J.V. (2013). Reactions to Recruitment Web Sites: Visual and Verbal Attention, Attraction, and Intentions to Pursue Employment, Journal of Business and Psychology, 28, 263-285.

Alonso, R. (2014). Recruitment and Selection in Organizations. Retrieved from http://eprints.lse.ac.uk/58673/

Berger, L.A. \& Berger, D.R. (2011). The Talent Management Handbook $\left(2^{\text {nd }}\right.$ ed.), New York: The McGrawHill.

Billsberry, J. (2007). Experiencing Recruitment \& Selection, West Sussex: John Wiley \& Sons.

Breaugh, J.A. (2008). Employee Recruitment: Current Knowledge and Important Areas for Future Research, Human Resource Management Review, 18, 103-118. 
Carless, S.A. (2005). Person-Job Fit versus Person-Organization Fit as Predictors of Organizational Attraction and Job Acceptance Intentions: A Longitudinal Study, Journal of Occupational and Organizational Psychology, 78, 411-429.

Chapman, D.S., Uggerslev, K.L., Carroll, S.A., Piasentin, K.A., \& Jones, D.A. (2005). Applicant Attraction to Organizations and Job Choice: A Meta-Analytic Review of the Correlates of Recruiting Outcomes, Journal of Applied Psychology, 90 (5), 928-944.

Chien, C. \& Chen L. (2008). Data Mining to Improve Personnel Selection and Enhance Human Capital: A Case Study in High-Technology Industry, Expert Systems with Application, 34, 280-290.

Chowdury, S. (2002). The Talent Era: Achieving a High Return on Talent, New Jersey: Prentice Hall.

Cosseboom, L. (2014). 10 Things You Need to Consider before Investing in Indonesia. Retrieved from https://www.techinasia.com/10things-you-need-to-consider-beforeinvesting-in-indonesia.

Dessler, D. \& Huat T.C. (2009). Human Resource Management: An Asian Perspective $\left(2^{\text {nd }} e d.\right)$, Singapore: Prentice Hall.

Kapse, A.S., Patil, V.S., \& Patil, N.V. (2012). E-recruitment, International Journal of Engineering and Advanced Technology, 1 (4).

Klotz, A.C., Veiga, S.P.D.M., Buckley, M.R., \& Gavin, M.B., (2013). The Role of Trustworthiness in Recruitment and Selection: A Review and Guide for Future Research, Journal of Organizational Behavior, 34, 104-119.

Kraichy, D. \& Chapman, D.S. (2014). Tailoring Web-Based Recruiting Messages: Individual Differences in the Persuasiveness of Affective and
Cognitive Messages, Journal of Business and Psychology, 29, 253268.

Landy, F.J. \& Conte, J.M. (2013). Work in the $21^{\text {st }}$ Century: An Introduction to Industrial and Organizational Psychology (4 ${ }^{\text {th }}$ ed.), New Jersey: John Willey \& Sons Inc.

Mello, J.A. (2015). Strategic Human Resource Management, Stamford, Calif.: Cengage Learning.

Mondy, R.W. (2010). Human Resource Management ( $11^{\text {th }}$ ed.), New Jersey: Pearson Education.

Nikolaou, I. (2014). Social Networking Web Sites in Job Search and Employee Recruitment, International Journal of Selection and Assessment, 22(2).

Padgett, M.Y., Padgett, R.J., \& Morris, K.A. (2015). Perceptions of Nepotism Beneficiaries: The Hidden Price of Using a Family Connection to Obtain a Job, Journal of Business and Psychology, 30, 283-298.

Raub, S. \& Streit, E.M. (2006). Realistic Recruitment: An Empirical Study of the Cruise Industry, International Journal of Contemporary Hospitality Management, 18(4), 278-289.

Schultz, D. \& Schultz, S.E. (2006). Psychology and Work Today (international ed.), New Jersey: Pearson Education.

Scullen, S.E. (2013). What if the Preferred Applicant Rejects a Job Offer? A Look at Smaller Applicant Pools, Journal of Business and Psychology, 28, 331-344.

Shapiro, J.C., Hoque, K., Kessler, I., Pepper, A., Richardson, R., \& Walker, L. (2013). Human Resource Management, London: University of London.

Snell, S. \& Bohlander, G. (2010). Principles of Human Resource Management (international ed.), Canada: Nelson Education. 
Spector, P.E. (2012). Industrial and Organizational Psychology: Research and Practice ( $6^{\text {th }}$ ed.), Singapore: John Wiley \& Sons.

Stoughton, J.W., Thompson, L.F., \& Meade, A.W. (2015). Examining Applicant Reactions to the Use of Social Networking Websites in Preemployment Screening, Journal of Business and Psychology, 30, 73-88.
Townsend, K. (2007). Recruitment, Training, and Turnover: Another Call Centre Paradox, Personnel Review, 36(3), 476-490.

Zhao, H. \& Liden, R.C. (2011). Internship: A Recruitment and Selection Perspective, Journal of Applied Psychology, 96(1), 221-229. 